\title{
PERANCANGAN SISTEM APLIKASI E-TOLL INVENTORY BERBASIS JAVA WEB PADA PT JMTM
}

\author{
Edy Nugroho', Nahot Frastian' ${ }^{2}$, Fery Rahmawan Asma ${ }^{3}$ \\ Program Studi Teknik Informatika, Fakultas Teknik dan Ilmu Komputer, \\ Universitas Indraprasta PGRI \\ Jalan Raya Tengah No 80, Kelurahan Gedong, Pasar Rebo, Jakarta Timur \\ edi.nugroho11@yahoo.com ${ }^{1}$, dosen.nahot.frastian@gmail.com², ferytijang489@gmail.com
}

\begin{abstract}
Abstrak
Perancangan sistem informasi pengelolaan data barang pada PT JMTM ini berfokus pada keluar masuk barang di dalam gudang penyimpanan. Karena pada perusahaah ini masih menggunakan pencatatan manual di beberapa proses penerimaan barang, pengeluaran barang dan bahkan pencatatan data barang di gudang, itupun hanya mengadalkan program pencatatan Microsoft Excel. Dengan adanya sistem ini di harapkan bisa mempermudah pekerjaan pengontrolan persediaan barang itu sendiri. $R \& D$ (Research \& Development) adalah merupakan salah satu jenis penelitian yang banyak di kembangkan oleh banyak peneliti, penelitian dan pengembangan merupakan salah satu jenis penelitian yang dapat menjadi penghubung atau pemutus kesenjangan antara peneliti dasar dengan peneliti terapan. Menurut Gay (14:2010). Dari hasil penelitian yang dilakukan di PT JMTM secara langsung maka, perancangan sistem aplikasi $e$-toll inventory berbasis java web ini dapat memecahkan masalah yang selama ini di hadapi, diantaranya mempersingkat waktu pekerjaan pengontrolan persediaan barang dari mulai permintaan, penerimaan, pengeluaran, menjadi lebih efiktif dan efisien.
\end{abstract}

Kata Kunci: Pengelolaan data, Penelitian, R\&D dan Inventory.

\begin{abstract}
The design of goods data management information system at PT JMTM focuses on the in and out of goods in the storage warehouse. Because in this company still use manual recording in some processes of goods receipt, expenditure of goods and data recording of goods in the warehouse, it is also only in the recording program Microsoft Excel. With this system is expected to facilitate the work of controlling the inventory of goods itself. $R \& D$ (Research \& Development) is one type of research that is widely developed by many researchers, research and development is one type of research that can be a link or break the gap between basic researchers and applied researchers. According to Gay (14:2010). From the results of research conducted at PT JMTM directly, the design of e-toll application system Inventory based on java web can solve the problems that have been faced, including shortening the work time of controlling inventory of goods from the start of demand, acceptance, expenditure, to be more efficient and efficient.
\end{abstract}

Keywords: Data management, , research, $R \& D$ and Inventory.

\section{PENDAHULUAN}

Perkembangan teknologi yang cukup pesat dari waktu ke waktu membuat pekerjaan yang dilakukan manusia pada umumnya dapat diselesaikan dengan cepat. Teknologi merupakan salah satu alat bantu yang sering digunakan dalam aktivitas manusia. Peran serta teknologi menjadikan pengolahan informasi menjadi semakin mudah karena pengolahan sangat diperlukan agar informasi yang dihasilkan dapat bermanfaat bagi penggunanya. Pengolahan data dan informasi secara cepat, tepat dan efisien adalah hal penting yang dibutuhkan bagi setiap perusahaan atau suatu instansi untuk meningkatkan produktifitas perkerjaan, waktu dan biaya.

Seiring berkembangnya kemajuan teknologi informasi dan komunikasi, persaingan bisnis dalam dunia industri semakin ketat. Jumlah perusahaan semakin banyak dan terus melakukan usaha dan strategi dalam mempertahankan bisnisnya. Kesuksesan perusahaan dalam mempertahankan bisnisnya tidak terlepas dari peran perusahaan tersebut dalam mengelola barang sehingga dapat memenuhi permintaan dari pelanggan semaksimal mungkin. Perusahaan yang mampu 
mengendalikan dan mengelola persediaan dengan baik akan dapat memenuhi kebutuhan pelanggan dan tentu saja dapat menjaga kelangsungan bisnisnya dalam industri saat ini.(Muttaqin and Musadieq n.d.)

PT JMTM ini juga sudah memiliki tempat atau bengkel sendiri untuk mengelola perawatan dan perbaikan di beberapa unit alat berat ataupun unit kendaraan pengankut alat berat nya tersebut, untuk melakukan pemeliharaan dan perbaikan di tiap-tiap unitnya, perusahaan ini melakukan beberapa kegiatan perawatan dan perbaikan di bengkelnya sendiri seperti perawatan rutin penggantian oli ,filter dan lain-lain. Begitu juga perbaikan yang dilakukan perusahaan ini dikerjakan sendiri di bengkel tersebut seperti perbaikan roda, ban, bak kendaraan pengankut dan lainya .

PT JMTM ini pun mempunyai gudang tempat penyimpanan barang-barang perbaikan, perawatan dan lainya. Pengawasan dan pencataan terhadap penggunaan barang - barang tersebut juga dilakukan oleh admin gudang melalui beberapa prosedur pencataan barang seperti barang masuk, barang keluar dan setok barang tersebut. Sebagian prosedur yang terdapat di PT JMTM ini belum semuanya menggunakan sistem komputerisasi . Di dalam pemesanan dan penerimaan barang pun PT JMTM ini sebagian prosesnya masih menggunakan sistem manual walaupun terkadang sistem komputerisasi yang sudah ada di pergunakan dalam proses tersebut, itupun hanya sebatas pencatatanya saja .yang sering sekali mengalami banyak kesalahan di dalam pencatatan manual tersebut. Kesulitan dan kerumitan pada saat penghitungan akhir stok pun terkadang muncul karna banyaknya proses yang di kerjakan secara manual. Suatu masalah tersebut akan dicarikan solusi yang bisa di terapkan pada perusahaan ini, di antaranya dengan mencoba membuat sistem pencatatan yang terintegrasi didalam gudang dan terrekan secara sistematis pada setiap prosesnya.

Tujuan dari penelitian ini adalah membuat aplikasi yang dapat memudahkan perusahaan dalam mengelola data barang dan membantu pekerjaan admin dalam mengontrol persediaan barang di gudang menjadi lebih efisien waktu pengerjaanya.

\section{PENELITIAN RELEVAN}

Penelitian (Informatika et al. 2018), dengan judul "Rancangan dan bangun sistem informasi Inventory barang berbasis web". Penelitian tersebut bertujuan untuk membuat sistem informasi inventori barang, yang dapat mengelola barang masuk dan keluar secara sistem komputerisasi berbasis web. Hasil penelitian ini dapat menghitung pemakaian barang dan penerimaan barang secara real time, cepat dan mudah untuk di gunakan. Penelitian oleh (Bilqis et al. 2018), dengan judul "Rancangan bangun aplikasi pembelian barang produksi berbasis web (pada UD Arbain Grafika Surabaya)". Penelitian ini juga bertujuan membangaun sebuah proses pendataan keluar masuknya barang berupa bahan baku produksi. Selain pendataan barang bahan baku produksi, berkas tagiahan atau pembayaran yang berbentuk dokumen juga menjadi tujuan agar bisa di selesaikan oleh sistem yang nantinya akan memudahkan pekerjaan. Hasil dari penelitian ini aplikasi berbasis web yang di rancang ini ternyata dapat menyelesaikan suatu permasalahan yang ada. Penelitian (Kepada et al. 2011) oleh dengan judul "Sistem informasi penerimaan siswa baru berbasis web dengan PHP dan SQL". Peneliti tersebut menjelaskan beberapahal di dalam tulisanya ini, tentang sistem aplikasi berbasis web yang menggunakan bahasa pemrograman PHP dan database SQL sejauh ini bahasa pemrograman web sudah banya macamnya salah satu PHP itu sendiri. Peneliti ini juga menggunakan metode penelitianya menggunakan Researd and Development ( $R \& D)$, dan juga waterfall model untuk pengembangan perangkat lunaknya. Karenanya pelitian yang seperti ini sudah banyak dilakukan oleh banyak peneliti-peneliti lain dan memudahkan dalam mendekteksi masalah serta menganalisis permasalahan. Hasil dari penelitian tersebut sistem penerimaan siswa baru berbasis web dengan bahasa pemrograman PHP dan SQL ini mampu mengatasi masalah yang ada. Penelitian (Keislaman 2017) dengan judul "Konsep penelitian R \& D dalam bidang pendidikan" penelitian ini menerangkan bahwa metode researd and development itu adalah salah satu metode penelitian yang bertujuan untuk menghasilkan produk-produk tertentu serta menguji validitas dan keefektifan produk.

Menur Rshmawati (2017) Universitas Islam Negri Raden Fatah Palembang, Judul : "Sistem Informasi Inventory Stok Barang Pada Cv.Artha" Simpulan : Sistem informasi Inventory di bangun untuk dapat mendata transaksi pesana, pengiriman, barang masuk atau keluar dan transaksi pembayaran yang 
sudah terkomputerisasi dengan adanya laporan dan grafik sehingga dapat mengetahui dan memberikan informasi yang cepat, tepat dan akurat setiap harinya.

Menurut Tsani (2016), Sekolah Tinggi Manajemen Informatika dan Komputer (YMI) Tegal, Judul Jurnal : "Sistem Informasi Persediaan Barang Berbasis Java PT.Andhika Sarana Mitra Jakarta Pusat", Simpulan : Dari hasil pembuatan aplikasi sistem informasi persediaan barang ini dapat mempermudah dan mempercepat kinerja petugas bagian gudang, dengan adanya aplikasi ini perusahhan dapat melihat persediaan barang dan dapat lebih teratur dalam proses transaksi persediaan barang. Kegiatan pencatatan transaksi pemesanan barang, penerimaan barang dan pengeluaran barang sudah memekai sistem komputerisasi walau hanya sebatas menggunakan Microsoft Excel.

Berdasarkan hasil penelitian penelitian yang telah dilakukan oleh peneliti sebelumnya menyimpulkan bahwa sebuah sistem informasi inventori barang yang menggunakan bahasa pemrograman web dapat menyelesaikan suatu permasalahan yang ada kaitanya dengan keluar, masuk dan perndataan barang yang cepat dan tepat. Penelitian rancangan sistem aplikasi $e$-toll iventory berbasis java web pada PT JMTM ini juga menggunakan metode penelitian yang sama yaitu menggunakan Reaserd and Development (R\&D).

\section{METODE PENELITIAN}

Penelitian ini dilakukan selama empat bulan yang terdiri dari bulan februari 2019 sampai dengan mei 2019 pada PT JMTM yang beralamatkan di sentul selatan dua, desa cipambuan, kecamatan babakan madang, bogor.

Research and Development (R\&D) adalah merupakan salah satu jenis penelitian yang banyak di kembangkan. Penelitian pengembangan merupakan salah satu jenis penelitin yang dapat menjadi penghubung atau pemutus kesenjangan antara penelitian dasa dengan penelitian terapan.

\section{Metode Pengumpulan Data}

Untuk mendapatkan data-data serta mengumpulkan informasi guna dukung penyempurnaan dari hasil penelitian ini, maka metode pengumpulan data yang dilakukan oleh peneliti antara lain.

\section{Studi Lapangan}

Agar bisa merancang sistem informasi tentang inventori gudang dan pencatatan keluar masuknya barang di gudang, maka peneliti medatangi langsung kelapangan tempat yang di jadikan objek penelitian. Observasi yang dilakukan oleh peneliti dengan mengamati semua kegiatan yang berlangsung di gudang yang nantinya berkaitan dengan sistem iventori gudang. Wawancara juga dilakukan peneliti untuk mengali informasi tentang sistem yang sudah berjalan dan kendala kendala yang dihadapi, sehinggan yang nantinya diharapkan bisa membantu proses perancangan sistem yang dilakukan peneliti.

\section{Studi Keputusan}

Yaitu memperoleh data sekunder dengan cara mengadakan studi pada perpustakaan, pengumpulan data dan informasi dari kutipan-kutipan, buku-buku, serta hasil laporan bahan lainya yang berkaitan dengan penelitian ini. Dari bahan-bahan tersebut diambil teori-teori yang dapat dijadikan landasan untuk mengatasi masalah yang ditemukan dalam penelitian informasi gudang dan pencatatan keluar masuk barang.

\section{Pencarian Informasi Melalui Internet}

Yaitu pencarian data dan sistem dengan cara mengunjungi beberapa website yang ada di internet untuk mengumpulkan kutipan-kutipan atau artikel-artikel yang berkaitan dengan penelitian ini yang terdapat pada penelitian yang relevan.

Identifikasi suatu sistem terhadap kebutuhan sistem yang baru harus dilakukan, tidak hanya didasarkan kebutuhan - kebutuhan pekerja dan perusahaan, tetapi juga dipandang dari manfaat sistem yang telah dibuat dengan sistem yang sudah ada sebelumnya. Adapaun tahapan-tahapan pada rancangan sistem ini metode yang digunakan yaitu metode waterfall yang meliputi proses - proses 
sebagai berikut: ada beberapa paradigma yang dapat digunakan dalam pengembangan pranti lunak, salah satunya adalah classic life cycle atau lebih dikenal dengan model waterfall.

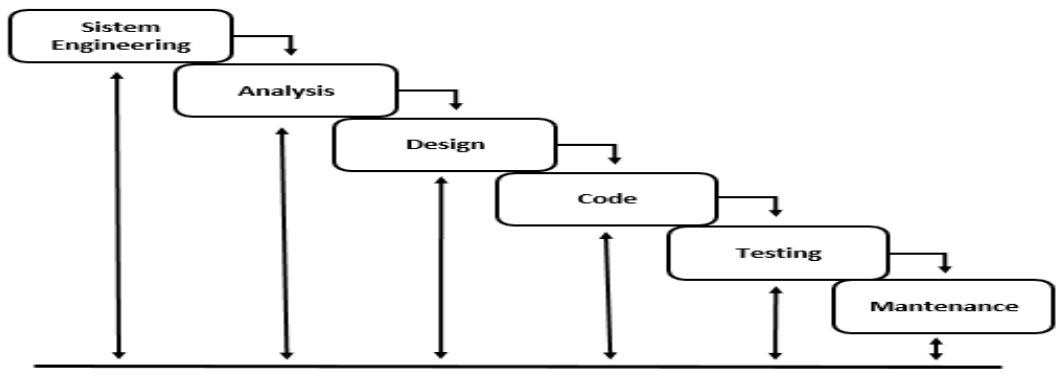

Gambar 1. Classic Life Cycle (Shofah n.d.)

\section{Sistem Engineering (Rekayasa Sistem)}

Rekayasa sistem adalah kumpulan konsep, pendekatan dan metodelogi, serta alat-alat bantu untuk merancang dan menginstalasi sebuah kompleksitas sistem. Kompleksitas sistem bisa diakibatkan karena dua hal kompleksitas dinamis dan kompleksitas detail. Kompleksitas detail ketika komponen atau sub-sistem yang dirancang tidak hanya banyak tetapi di tambah pula dengan multi sourching dan lainnya. (Informatika et al. 2018)

\section{Analisis (Analisis Data Dan Proses)}

Data merupakan kumpulan dari nilai-nilai yang mencerminkan karakteristik dari individu-individu dan suatu populasi. Data bisa berupa angka, huruf, suara maupun gambar. Dari data ini diharapkan akan diperoleh iniformasi sebesar-besarnya tentang populasi. Dengan demikian, perlu pengetahuan dan penguasaan metode analisis sebagai upaya untuk mengeluarkan informasi yang terkandung dalam data yang dimiliki. Kemudian ditahap menganalisa kebutuhan sistem dilakukan pengumpulan dengan berfokus pada perangkat lunak, meliputi: Sistem, Informasi, fungsi masing-masing pada bagian sistem, kerja atau cara kerja dan antarmuka. Lalu menyediakan perangkat dan teknik yang dapat membantu peneliti untuk menentukan kebutuhan melalui sistem yang telah berjalan pada rancangan sistem informasi iventory gudang dalam melakukan pengolahan data-datanya. Perangkat yang dimaksud adalah penggunaan Diagram Alir Data (DAD) untuk menyusun daftar input, proses dan output fungsi bisnis.(Shofah n.d.)

\section{Design (Perancangan)}

Perancangan adalah suatu kegiatan yang memiliki tujuan untuk medesign sistem baru yang dapat menyelesaikan masalah-masalah yang di hadapi pada perusahaan yang diperoleh dari pemilahan alternatif sistem yang terbaik. Pada tahapan ini dilaksanakan perancangan struktur data, arsitektur perangkat lunak, rincian prosedural, karakteristik antar muka dilaksanakan pada tahapan ini.(Wahyudi 2012)

\section{Coding (Pengkodean)}

Pengkodean (Encoding) adalah proses perubahan karakter data yang akan dikirim dari satu titik ke titik lain dengan kode yang dikenal oleh setiap terminal yang ada dan menjadikan setiap karakter data dalam sebuah informasi digital dalam bentuk biner agar dapat di transmisikan. Pada tahapan ini dibuat koding untuk mendapatkan sistem masuk dan keluarnya barang yang merupakan tahapan untuk membuat suatu kode tentang sofware yang akan dibuat agar dapat dibaca dan di terjemahkan oleh komputer.(Suzianti Rachma; Muslim, Erlinda 2015)

\section{Testing (Pengujian)}

Pengujian adalah proses yang bertujuan untuk memastikan apakah semua fungsi sistem bekerja dengan baik dan mencari kesalahan yang mungkin terjadi pada sistem. Sebelum sistem informasi keluar dan masuknya barang dapat digunakan dengan baik, harus dilakukan pengujian terlebih dahulu. 
Rangkaian pengujian ini dijalankan bersama-sama dengan data aktual dari sistem yang udah ada atau sistem yang sedang berjalan.(Abidin 2014)

\section{Implementasi \& Maintenace (Implementasi Dan Pemeliharaan)}

Pemeliharaan sistem adalah suatu kombinasi dari berbagai tindakan yang dilakukan untuk menjaga suatu sistem dalam atau memperbaikinya sampai suatu kondisi yang bisa diterima. Pemeliharaan dan penyempurnaan mempertinggi cara kerja atau maintainabilitas (kemampuan untuk dipelihara). Tindakan ini juga memungkinkan sistem untuk memenuhi persyaratan pemakai yang sebelumnya tidak dikenal. Ketika membuat perubahan substansial modul apapun, petugas pemeliharaan juga menggunakan kesempatan untuk meng-upgrade kode, mengganti cabang-cabang yang kadarluarsa, memperbaiki kebocoran dan mengembangkan dokumentasi.

\section{HASIL DAN PEMBAHASAN}

Penelitian ini berhasil membuat sebuah aplikasi sistem informasi inventory barang berbasis web yang dapat mempermudah proses pendataan keluar, masuk barang secara sistematis. Aplikasi ini juga memberikan kemudahan dalam pencarian barang dan mengetahui informasi barang dengan cepat dan tepat. Tetapi sistem ini juga butuh pengembangan lebih lanjut untuk penyempurnaanya.

Rancangan antar muka atau dialog layar merupakan rancangan bangaun percakapan antara pengguna dengan komputer yang terdiri dari proses memasukan data ke sistem kemudian menampilkan kembali output informasi kepada pengguna dengan uraian sebagai berikut.

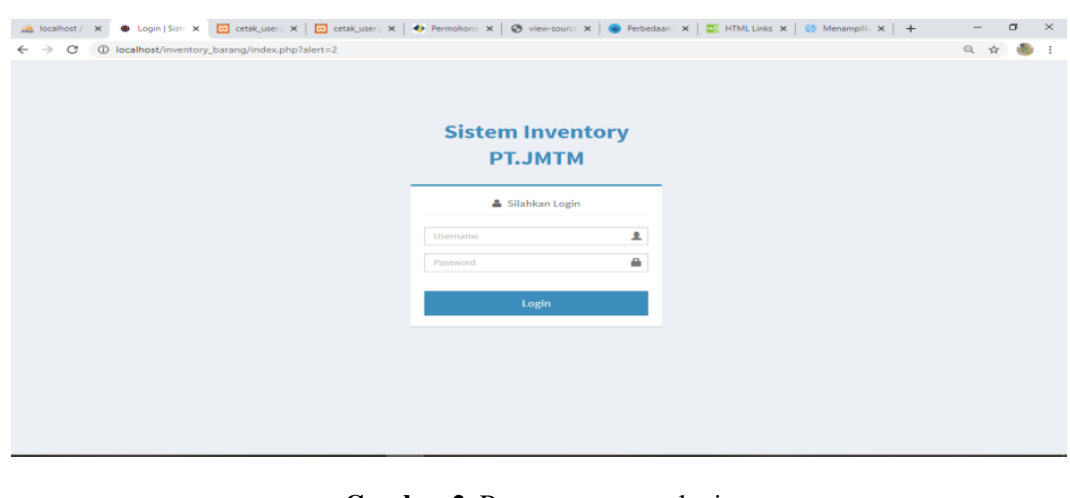

Gambar 2. Rancangan menu login

Rancangan ini terdapat pada awal program. Menu login digunakan sebagai kata kunci sebelum kita memasuki menu utama. Agar tidak sembarang orang dapat mengakses program ini, sehingga dalam form menu terjaga kerahasiaanya tetap terjaga dengan baik.

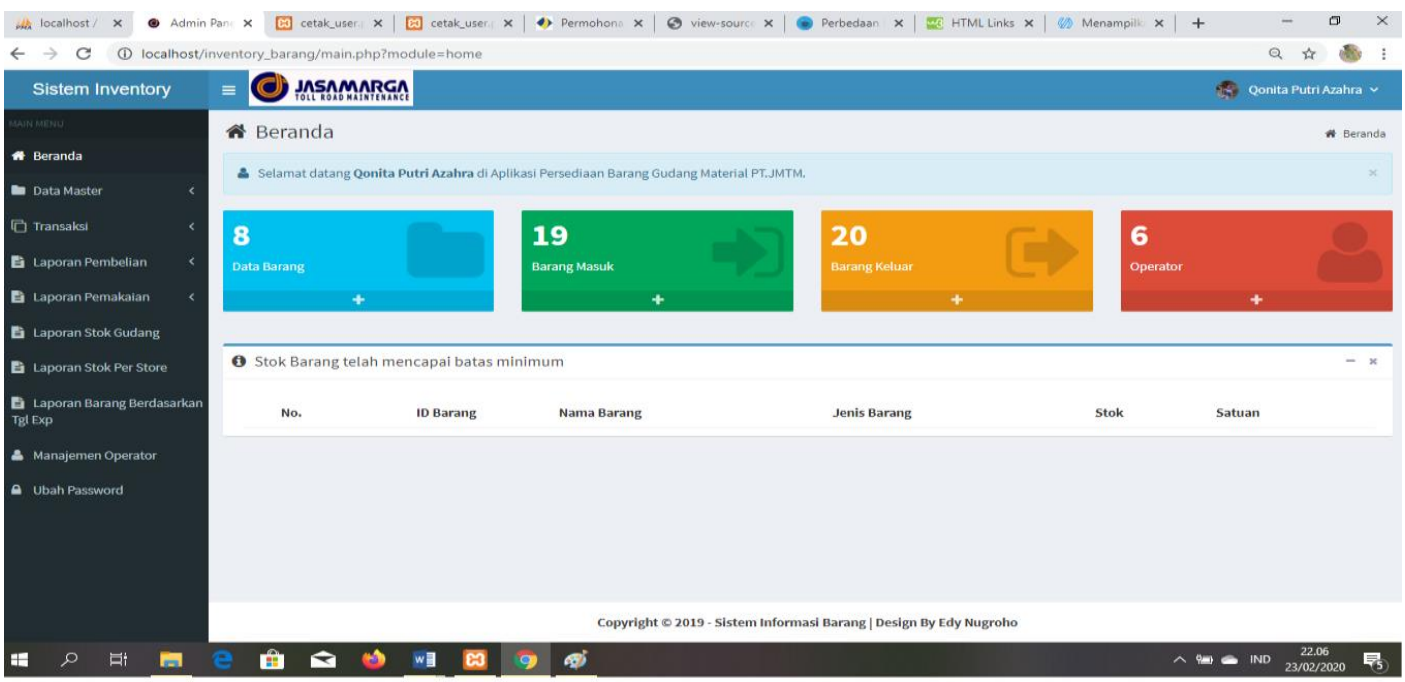

Gambar 3. Rancangan tampilan menu 
Layar di atas menampilkan tampilan menu control sistem inventory barang pada PT JMTM. Pada layar menu utama tersedia menu bar yang terdiri dari menu akses yang digunakan pada saat pengguna ingin login atau exit dari aplikasi, menu berkas yang digunakan untuk memasukan data yang berkaitan dengan data barang.

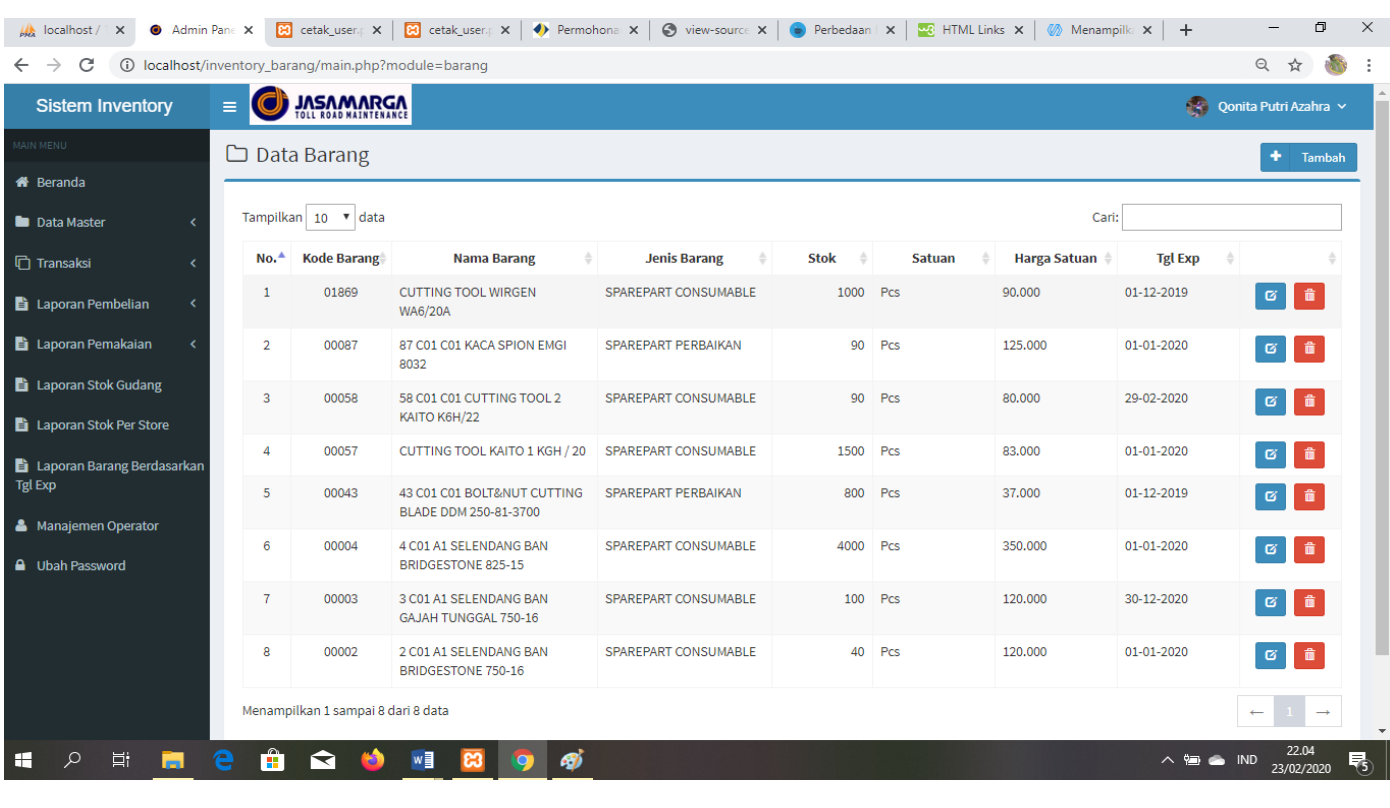

Gambar 4. Rancangan tampilan data barang

Pada tampilan di atas merupakan rancangan tampilan form data barang. Form ini memiliki beberapa tombol yang terdiri dari tombol untuk menambah data baru, menyimpan data baru yang telah di masukan dan tombol untuk menghapus data yang sudah di tambahkan.

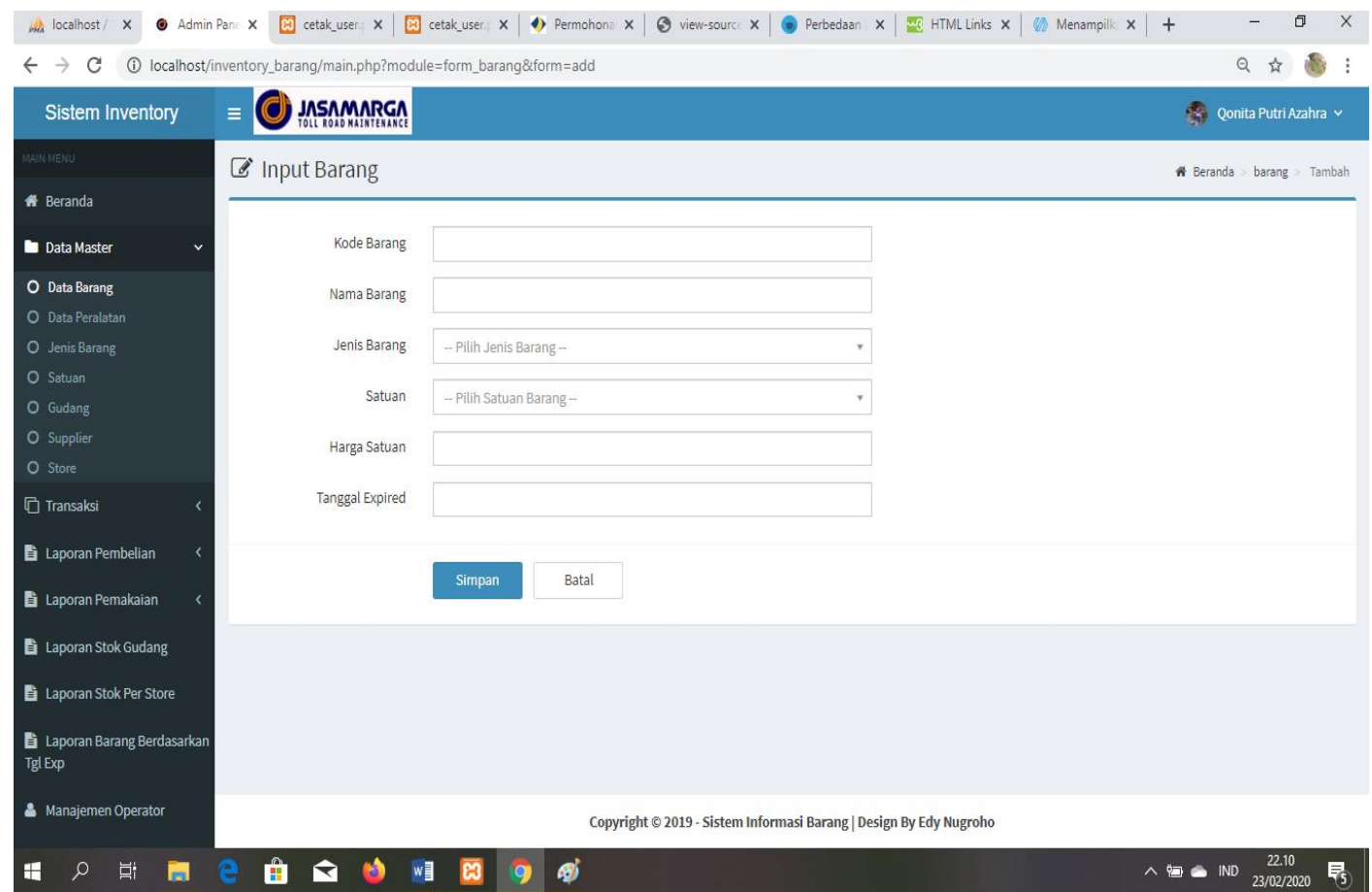

Gambar 5. Rancangan tampilan form input data barang

Layar di atas merupakan rancangan tampilan form data pemasikan barang yang di gunakan untuk memasukan data-data barang. Pada form ini juga terdapat tombol batal yang dapat digunakan untuk membatalkan inputan yang sudah di input. 
JRAMI (Jurnal Riset dan Aplikasi Mahasiswa Infarmatika)

Vol QZ No II Tahun ZQZI

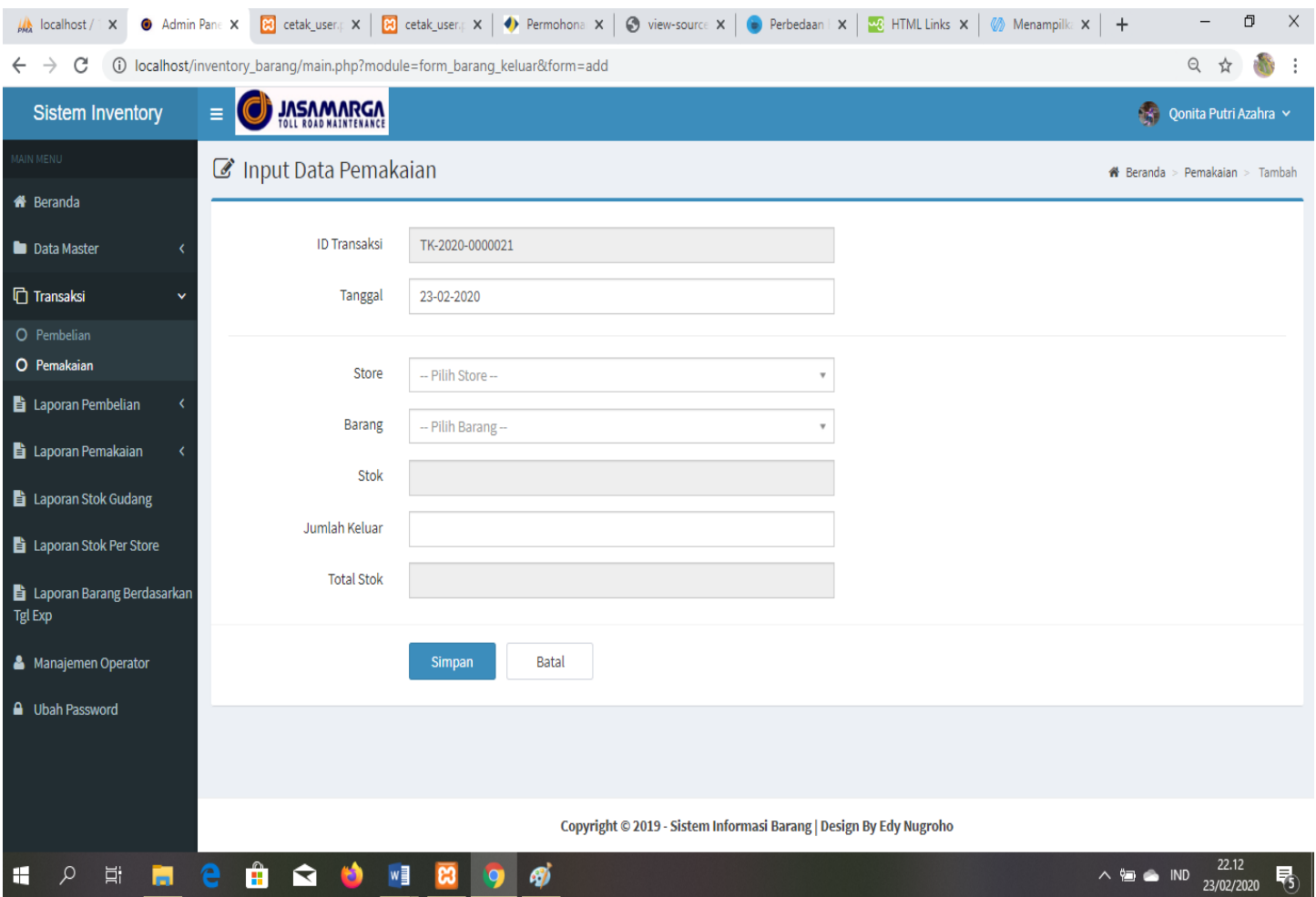

Gambar 6. Rancangan form pengeluaran

Pada rancangan tampilan form pengeluaran barang sama halnya dengan rancangan form pemasukana data barang memiliki beraberapa tombol untuk melakukan penyimpana dan pembatalan pendataan barang yang akan di keluarkan. Form ini juga memiliki tombol untuk pindah ke menu utama.

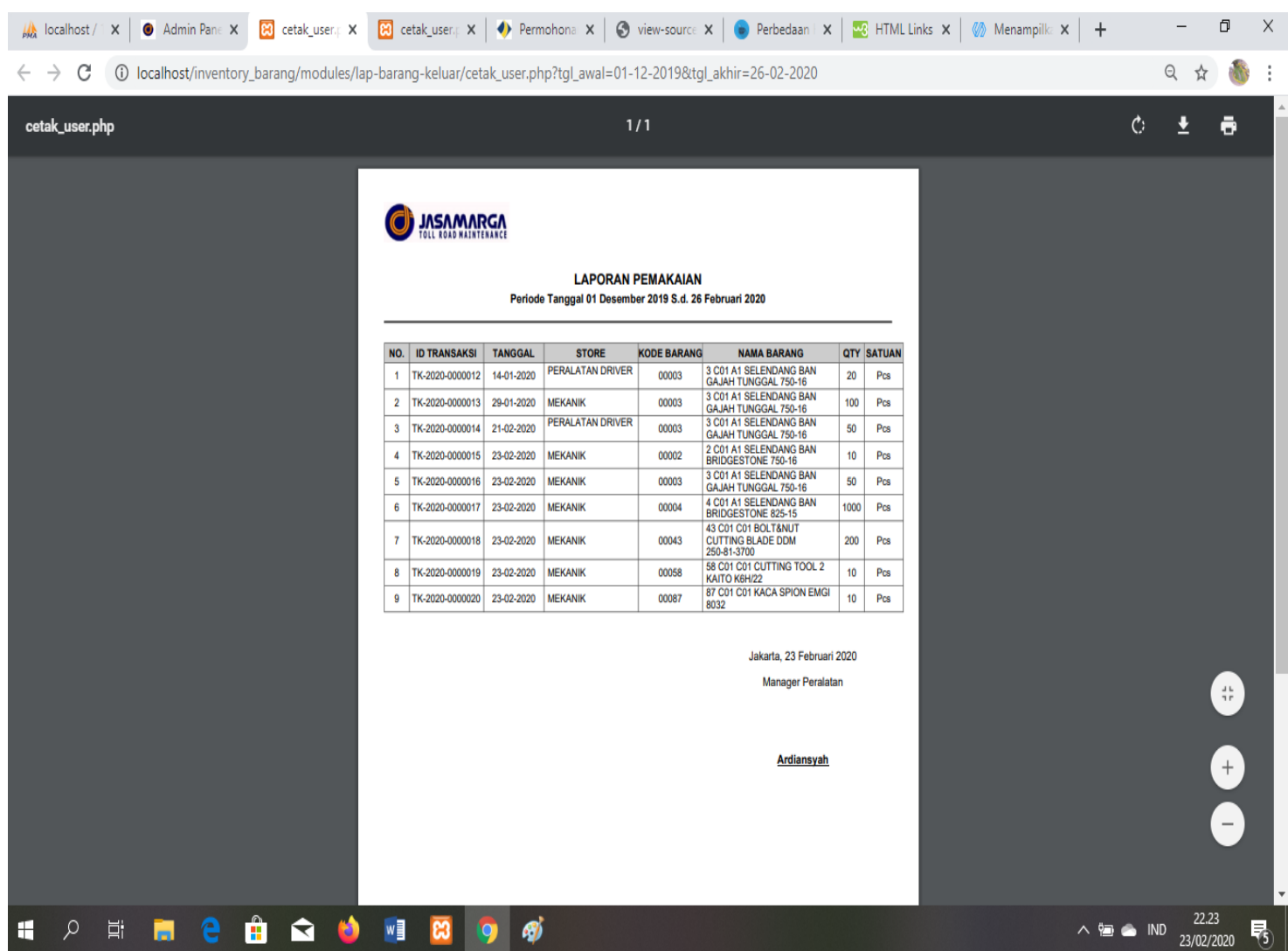

Gambar 7. Rancangan tampilan laporan pengeluaran 
Pada rancangan ini menampilkan laporan pengeluaran barang. Dalam hal ini terdapat beberapa laporan yang dapat di cetak diantaranya laporan pengeluaran barang. Disini user menyarig terlebih dahulu batasan tanggal pengeluaran barang dan kemudian menekan tombol print untuk menampilkan laporan hasil pengeluaran.

\section{SIMPULAN}

Dengan dibuatnya aplikasi sistem informasi inventory barang pada PT JMTM semua kegiatan yang berhubungan dengan pengolahan data inventory barang dapat berjalan dengan baik dan lancar. Dengan adanya aplikasi ini diharapkan akan mempermudah kegiatan atau aktivitas pekerjaan yang memerlukan kecepatan dan ketepatan informasi. Kecepatan dan ketepatan ini juga membutuhkan partisipasi aktif dari pemakai sistem informasi, terutama kedisiplinan para pelaksana yang menangani secara langsung pada sistem informasi yang di rancang.

\section{DAFTAR PUSTAKA}

Abidin, Muhammad Sofyan. 2014. "Dampak E-Money.” Igarss 2014 (1): 1-5.

Bilqis, Maharani et al. 2018. "ISSN 2338-137X Rancang Bangun Aplikasi Pembelian Bahan Produksi Berbasis Web Pada UD Arbain Grafika Surabaya." 7(1): 1-5.

Informatika, Teknik, Universitas Ibn Khaldun, J1 K H Sholeh, and Iskandar Raya. 2018. "RANCANG DAN BANGUN SISTEM INFORMASI INVENTORI BARANG BERBASIS WEB ( STUDI KASUS PT . NUSANTARA SEJAHTERA RAYA ) Maulana Hasanudin Jurnal IKRA-ITH Informatika Vol 2 No 3 November 2018 ISSN 2580-4316.” 2(3): 24-37.

Keislaman, Kajian. 2017. “KONSEP PENELITIAN R \& D DALAM BIDANG PENDIDIKAN.” m(1989): 129-50.

Kepada, Diajukan et al. 2011. "BERBASIS WEB DENGAN PHP DAN SQL."

Muttaqin, Fikri, and Mochammad Al Musadieq. "UNTUK PERSEDIAAN BARANG PADA TOKO BAHAN BANGUNAN ( Studi Kasus Pada UD . Sumber Bumi Subur ).” 8(1): 1-7.

Rshmawati. 2017. "Sistem Informasi Inventory Stok Barang Pada Cv.Artha." 2017.

Shofah, Siti. "Pengembangan Aplikasi Pengelolaan Barang Berbasis Web Pada Pt. Telkom Kandatel Jakarta Selatan."

Suzianti Rachma; Muslim, Erlinda, Amalia; Hidayati. 2015. "Perancangan Roadmap Produk Dan Teknologi Pada Uang Elektronik Chip-Based Di Indonesia.” Jurnal Manajemen Teknologi 14(Vol 14, No 1 (2015)): 35-46.

Tsani, M.Rifqi. 2016. “Sistem Informasi Persediaan Barang Berbasis Java PT.Andhika Sarana Mitra Jakarta Pusat." 2016.

Wahyudi, Johan. 2012. "Dokumen Elektronik Sebagai Alat Bukti Pada Pembuktian Di Pengadilan." Perspektif 17(2): 118-26. 